\title{
Congenital Heterochromia: A Case Report
}

\section{Konjenital Heterokromi: Olgu Sunumu}

\author{
Rahmi Duman ${ }^{1}$, Melisa Zişan Karslığlu², Ceyda Başkan ${ }^{1}$, Sabite Emine Gökçe ${ }^{2}$ \\ ${ }^{1}$ Dr. A. Y. Ankara Onkoloji Eğitim Ve Araştırma Hastanesi, Göz Hastalıkları, Ankara, Türkiye \\ ${ }^{2}$ Özel Kudret Göz Hastanesi
}

Doi: $10.5505 /$ aot.2012.41636

\section{ÖZET}

Heterokromi iridis genellikle her iki göz rengi arasında fark olmasıyla tanımlanan nadir görülen bir durumdur. Sendromik bir hastalığın komponenti, bir göz hastalığının sonucu veya konjenital olarak ortaya çıkabilmektedir. Biz bu çalışmada konjenital heterokromili bir hastayı sunmayı amaçladık.

Anahtar Kelimeler: Heterokromi; Konjenital; İris

\section{ABSTRACT}

Heterochromia iridis is a rare condition that often defined as eye color difference between the two eyes. It can be congenital or either a component of a syndromic disease or a result of an eye disease. In this study, we aimed to present a patient with congenital heterochromia.

Anahtar Kelimeler: Heterokromi, konjenital; iris

\section{Giriş}

İris pigmentasyonunda farkl11ık anlamına gelen heterokromi, literatürde lokalizasyonu açısından iki başlık altında incelenmektedir; sektöriyel heterokromi ve binoküler heterokromi. Sektöriyel heterokromide iris farklı renkte bölgeler içermekte iken bilateral olarak da görülebilmektedir. Binoküler heterokromide ise etkilenen irisin tamaminda renk değişikliği izlenmektedir, diğer gözde her hangi bir patoloji yoktur (1).

Biz bu çalışmada nadir görülen konjenital binoküler heterokromili bir hastayı sunmay1 ve heterokromili hastaların klinikte nasıl değerlendirilmesi gerektiğini tartışmayı amaçladık.

\section{Olgu}

On iki yaşında, erkek hasta, polikliniğimize rutin kontrol amaciyla ailesi tarafindan getirildi. Hastanın yapılan ayrıntılı oftalmolojik muayenesinde en iyi düzeltilmiş görme keskinliği sağ-sol camsız 10/10 idi. Ultrasonografide, biyomikroskopik ve fundus muayenesinde heterokromi dişında her hangi bir patoloji saptanmadi (Resim 1). Her iki gözde kapak aralıkları eşit ölçülürken, gözler arası pupilla çapında bir farklılık saptanmadı.

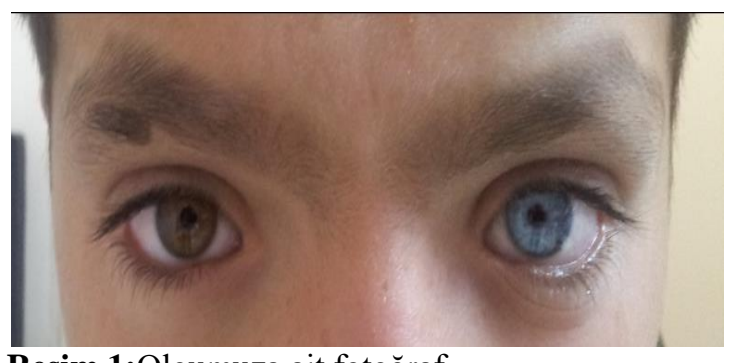

Resim 1:Olgumuza ait fotoğraf

Aile öyküsü sorgulandığında benzer bulgulara sahip kimsenin olmadığ 1 öğrenildi. Genel sistemik muayene için çocuk hastalıkları bölümüne konsülte edilen hastada eşlik eden sistemik bir patolojiye rastlanmadı. Diğer tanılar dişlanan hastaya konjenital heterokromi tanisı konuldu.

\section{Tartışma}

İris embriyolojik olarak iki farklı kökenden gelişmiş iki tabakadan meydana gelmektedir. Mezodermden gelişmiş olan ön tabaka iris stromasını ve nöroektodermden gelişmiş olan arka tabaka ise posterior pigment epitelini oluşturmaktadır. İris stroması; pupilla dilatör/sfinkter kasları, kan damarları, sinirleri, 
fibroblast, melanosit ve mast hücrelerini içermektedir. Posterior pigment epiteli ise oldukça fazla sayıda hücrelerarası sıkı bağlantı ile birbirlerine bağlı iki sıra küboid pigment hücrelerinden meydana gelmektedir (1).

Göz rengi posterior pigment epiteli içindeki pigment granülleri, stromal melanositlerin içerdiği pigment yoğunluğu, melanositlerdeki melanin pigmentinin niteliği ve hücre dış1 stromal matriksin 1 şığı dağıtma ya da çekme özelliğine bağlı olarak değişmektedir $(2,3)$. Binoküler heterokromi tarihçilerce oldukça eski zamanlardan beri tanımlanmıştır. Bizans imparatorlarından Anastasius I'in de sağ gözünde olgumuza benzer şekilde renk değişikliği bulunduğu, sol gözünün siyah olduğu anlatılmaktadır. Bilindiği kadarıyla oldukça uzun yaşamış ve bu süre zarfında her hangi bir hastalıktan yana şikayeti olmamıştır (4). Başka ünlü bir Yunan tarihçi Plutarkhos ise Büyük İskender'de binoküler heterokromi varlığını bildirmiştir (5).

Heterokromi etyopatogeneze göre konjenital ya da edinilmiş olarak sınıflan- dirılabilmektedir. Konjenital sebepleri; konjenital Horner sendromu (anizokori, servikal nöroblastom, karotis diseksiyonu, karotis arter hipoplazisi), Waardenburg sendromu (sensörinöral işitme kaybı, iris, saç ve ciltte pigmenter değişiklikler, kraniyofasiyal dimorfizm), Parry-Romberg sendromu (konjenital fasiyal hemiatrofi, ciddi baş ağrısı, epilepsi), Suturge-Weber sendromu (yüzde nevüs flammevus, aynı tarafta merkezi sinir sistemi hemanjiyomları, epilepsi, hemiparezi, hemianopsi, iris, siliyer cisim ya da koroid hemanjiyomlar1, glokom) gibi sendromlar oluşturur. Edinilmiş sebepleri; oküler travma, ilaç kullanımı (antiglokomatöz tedavide kullanılan prostaglandin analogları), melanositik infiltrasyon (diffüz iris nevüsü ya da melanomu), yabancı cisim (oküler siderosis), edinilmiş Horner sendromu, Fuchs heterokromik iridosikliti (görme keskinliğinde azalma, keratik presipitatlar, katarakt, sekonder glokom) oluşturmaktadır (Tablo1) (6).

Tablo1: Heterokromi ayırıcı tanıs1

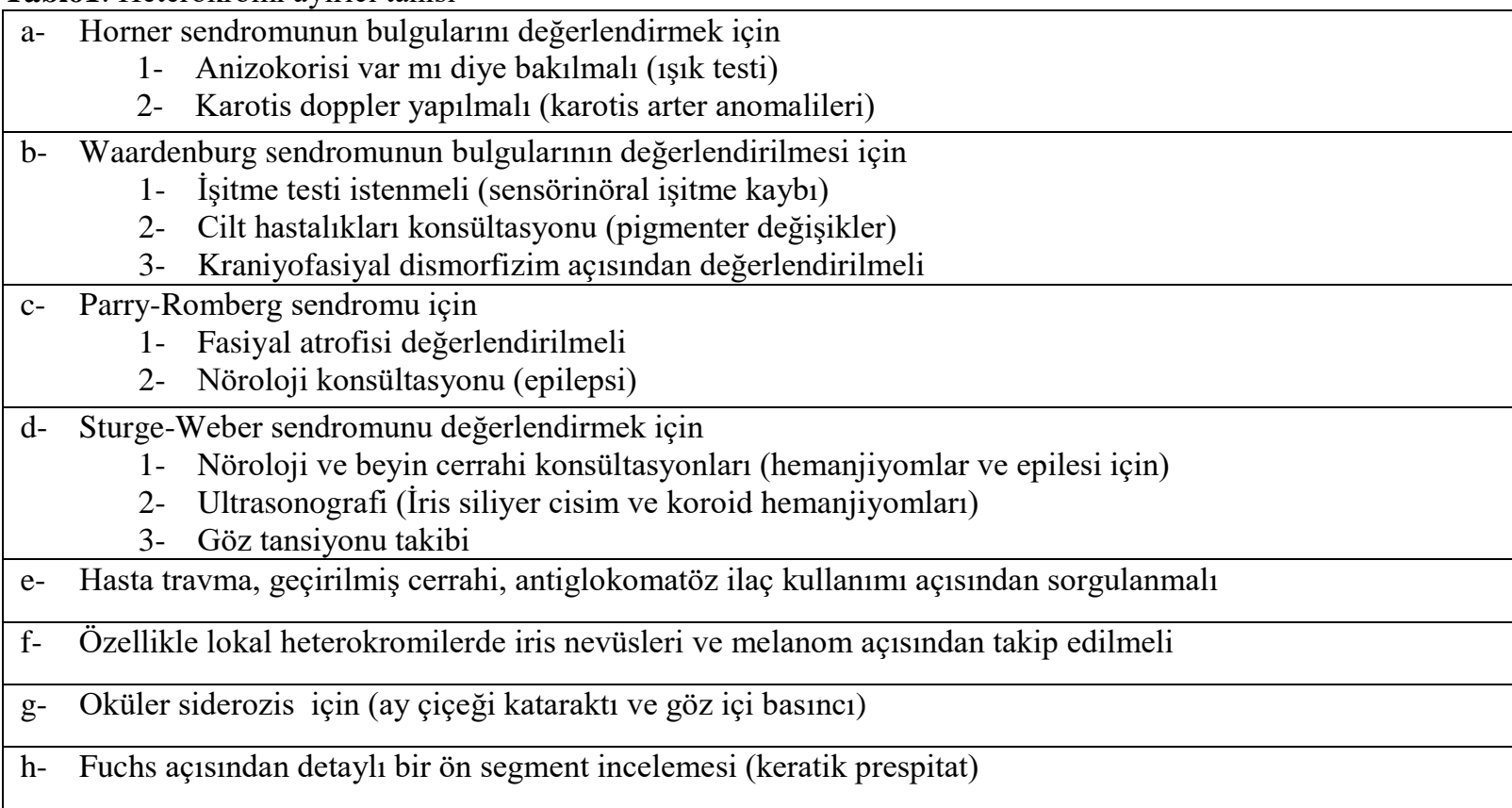

Olgumuzun ayrıntılı oftalmolojik ve sistemik muayeneleri sonucunda, diğer nedenleri dışlayarak konjenital binoküler heterokromi tanısı koyduk. İzole konjenital bir anomali şeklinde ortaya çıkabildiği gibi otozomal dominant geçiş de görülebilmektedir
(5). Heterokromili bir olgu ile karşılaşıldığında öncelikle heterokromi sektöryel mi yoksa binoküler mi değerlendirilmeli, ayrıntılı bir oftalmolojik bir muayene yapılmalı ve mutlaka nöroloji konsültasyonu incelenmelidir. 
Sonuç olarak herhangi bir olguda heterokromi saptandığında titizlikle etyo-

\section{Çıkar Çatışması: Yok.}

\section{Referanslar}

1- Rennie IG. Don't it make my blue eyes brown: heterochromia and other abnormalities of iris. Eye 2012;26:29-50

2- Prota G, Hu DN, Vincensi MR, McCormick SA, Napolitano A. Characterization of melanins in human patogenez araştırılmalı, altta yatan olası hastalıklar açısından dikkatli olunmalıdır.

iridis and cultured uveal melanocytes from eyes of different colors. Exp Eye Res 1998;67:293-9

3- Lascaratos J. 'Eyes' on the thrones: imperial ophthalmologic nicknames. Surv Ophthalmol 1999;44:73-8

4- Duke Elder S. System of ophthalmology, Henry Kimpton: London, 1964

5- Ur Rehman H. Heterochromia. CMAJ 2008;179:4478 